\title{
KESEIMBANGAN PEKERJAAN DAN KEHIDUPAN PRIBADI SERTA GAYA KERJA BARU, BAGAIMANA DAMPAKNYA TERHADAP STRES KERJA?
}

\section{WORK-LIFE BALANCE AND NEW WAYS OF WORKING, HOW IS THE IMPACT ON JOB STRESS?}

\begin{abstract}
Oleh :
Tsalitsa Haura Syarifah ${ }^{1}$

Arum Etikariena ${ }^{2}$

ABSTRACT

Work-life balance and new ways of working are predicted to influence job stress. The study aims at discover the effect of work-life balance and new ways of working towards job stress. This research uses online questionnaires consisting of job stress (Shukla \& Srivastava, 2016), work-life balance (Bell, Rajendran, \& Theiler, 2012), and new ways of working scales (Van Steenbergen, et al., 2018). The result indicates that work-life balance has negative and significant effect on job stress $(\beta=-$ $0,56, p<0,01)$. However, new ways of working have no effect on job stress $(\beta=0,37, p>0,05)$. The result of multiple regression analysis shows that work-life balance and new ways of working are collectively able to predict job stress $\left.F(2,151)=33,98, R=0,56, p<0,01, R^{2}=31 \%\right)$. It means work-life balance and new ways of working simultaneously give a $31 \%$ variation in job stress, while the rest of $69 \%$ is explained by other factors that are not measured here.

Keywords: Job Stress; Work-Life Balance; New Ways of Working.
\end{abstract}

\section{ABSTRAK}

Work-life balance yang selanjutnya disebut keseimbangan kehidupan-kerja dan gaya kerja baru merupakan faktor prediktor yang diduga berpe ngaruh terhadap stres kerja. Penelitian ini hendak mengetahui pengaruh keseimbangan kehidupan-kerja dan gaya kerja baru terhadap stres kerja. Studi terhadap 154 karyawan kantor pusat PT Bank Syariah X menggunakan kuesioner online yang terdiri dari skala Job Stress (Shukla \& Srivastava, 2016), Work-Life Balance (Bell, Rajendran, \& Theiler, 2012), dan New Ways of Working (Van Steenbergen, dkk., 2018). Hasil menunjukkan bahwa keseimbangan kehidupan-kerja berpengaruh negatif dan signifikan terhadap stres kerja $(\beta=-0,56, p<0,01)$. Namun, gaya kerja baru tidak berpengaruh terhadap stres kerja $(\beta=0,37, p>0,05)$. Selanjutnya, hasil analisis regresi berganda menemukan bahwa keseimbangan kehidupan-kerja dan gaya kerja baru secara bersama-sama berpengaruh signifikan terhadap stres kerja, $\left.F(2,151)=33,98, R=0,56, p<0,01, R^{2}=31 \%\right)$. Temuan ini menyimpulkan bahwa $31 \%$ varians stres kerja dapat dijelaskan oleh keseimbangan kehidupan-kerja, sedangkan $69 \%$ sisanya dipengaruhi oleh faktor lain yang tidak diukur dalam penelitian.

Kata kunci: Stres Kerja,\; Keseimbangan Kehidupan-Kerja,〉; Gaya Kerja Baru.

\section{PENDAHULUAN}

Situasi pandemi covid-19 membawa berbagai dampak dan permasalahan bagi masyarakat Indonesia, termasuk kepada para karyawan yang menjalani transisi bekerja dari kantor dan dari rumah (Abidin, 2020). Pandemi Covid-19 berdampak pada aspek

\footnotetext{
${ }^{1}$ Tsalitsa Haura Syarifah, Fakultas Psikologi Universitas Indonesia, tsalitsa.haura@alumni.ui.ac.id

${ }^{2}$ Arum Etikariena, Fakultas Psikologi Universitas Indonesia, arum.etikariena@ui.ac.id
} 
Tsalitsa Haura Syarifah \& Arum Etikariena. Keseimbangan Pekerjaan Dan Kehidupan Pribadi Serta Gaya Kerja Baru, Bagaimana Dampaknya Terhadap Stres

individual seperti fisik, emosional, psikologis, hingga aspek masyarakat seperti ekonomi dan budaya (Hongwei \& Harris, 2020). Pada individu, kondisi ini memicu perasaan ketidakpastian, kebingungan, misinformasi, dan kegentingan sehingga mengakibatkan stres serta kepanikan di masyarakat (Taylor, 2019). Menghadapi situasi pandemi ini, tidak sedikit karyawan PT Bank Syariah X yang mengalami kondisi psikologis tidak menentu yang nantinya dapat memengaruhi produktivitas dalam bekerja (Puspaningtyas, 2020).

PT Bank Syariah X merupakan salah satu perusahaan swasta perbankan syariah. Beberapa tahun belakangan PT Bank Syariah X kembali dihadapkan pada kesulitan keuangan (Yahsyi, 2018). Banyaknya tantangan yang dilalui PT Bank Syariah X dalam beberapa tahun terakhir membuat karyawan PT Bank Syariah X perlu bekerja keras untuk mencapai target organisasi di tengah berbagai perubahan yang dihadapi, diantaranya pergantian manajemen puncak dan downsizing (Hendrianto, 2020). Menurut Cummings dan Worley (2015) downsizing merupakan intervensi untuk mengurangi biaya dan birokrasi dengan memperkecil skala organisasi melalui pengurangan jumlah karyawan (layoff), program pensiun dini, dan/atau mendesain kembali organisasi.

Dampak pelaksanaan downsizing di PT Bank Syariah X yakni berkurangnya jumlah karyawan yang cukup signifikan pada tiap unit kerja dan perubahan struktur di beberapa divisi. Karyawan kantor pusat PT Bank Syariah X dituntut untuk semakin produktif dengan beban kerja yang bertambah. Efek penambahan beban kerja ini menurut Cummings dan Worley (2015) dapat menimbulkan stres pada karyawan. Hal tersebut sesuai dengan temuan dari penelitian analisis organisasi yang dilakukan pada awal tahun 2020 bahwa karyawan mengeluhkan perihal beban kerja yang tinggi, sehingga membuat karyawan harus bekerja melebihi waktu yang ditentukan atau lembur.

Hasil analisis organisasi pada penelitian pendahuluan (preliminary study) yang dilakukan oleh peneliti pada Januari 2020 juga menunjukkan hal yang sama. 64,4\% dari 104 partisipan menyatakan bahwa karyawan merasa pekerjaannya saat ini cukup sering menuntut mereka untuk lembur. Hasil analisis organisasi berdasarkan kuesioner online tersebut juga menunjukkan salah satu aspek yang paling menonjol dirasakan karyawan adalah tingginya tingkat stres kerja. Hal ini terbukti dari dimensi stres kerja merupakan satu dari tiga dimensi yang dipersepsi paling tidak memuaskan bagi karyawan kantor pusat PT Bank Syariah X $(M=3,61)$ dan berada di bawah rata-rata skor keseluruhan kepuasan kerja $(M=4,01)$. Stres kerja menurut Shukla dan Srivastava (2016) yaitu respons fisik dan emosional yang mengganggu dan terjadi ketika tuntutan pekerjaan tidak sesuai dengan kapabilitas, sumber daya, dan kebutuhan karyawan.

Banyak faktor yang dapat menjadi prediktor stres kerja pada karyawan, baik faktor internal pada diri individu maupun faktor eksternal. Shukla dan Srivastava (2016) menemukan salah satu faktor internal penyebab stres kerja yang paling tinggi dirasakan oleh partisipan penelitiannya di India yaitu dikarenakan rendahnya work-life balance atau yang dalam penelitian ini selanjutnya disebut keseimbangan kehidupan-kerja. Shaffer, dkk. (2016) menambahkan, buruknya keseimbangan kehidupan-kerja memiliki dampak negatif terhadap kesehatan dan kesejahteraan karyawan, serta mempengaruhi performa organisasi. Ketidakseimbangan kehidupan-kerja menyebabkan tingkat stres yang lebih tinggi sehingga dapat meningkatkan intensi karyawan untuk keluar dari tempat kerjanya (Jaharuddin \& Zainol, 2019).

Kalpna dan Malhotra (2019) menjelaskan, keseimbangan kehidupan-kerja merupakan tingkat seberapa individu secara seimbang terlibat dan merasa puas dengan 


\section{Psycho Idea, Volume 19 Nomer 01 Tahun 2021}

pekerjaan dan peran di kehidupan pribadinya. Menurut Bell, Rajendran, dan Theiler (2012) keseimbangan kehidupan-kerja adalah sejauh mana seseorang dapat secara bersamaan menyeimbangkan tuntutan emosional, perilaku, dan waktu di antara pekerjaan, keluarga, dan kehidupan pribadi. Meskipun kondisi pandemi saat ini menghasilkan kebijakan bekerja dari rumah (work from home) dan memungkinkan para karyawan untuk bertemu dengan anggota keluarganya lebih sering, namun ketidakjelasan batasan kerja di rumah juga dapat berpengaruh terhadap keseimbangan kehidupan-kerja (Sullivan, 2012).

Sebelum masa pandemi, PT Bank Syariah X belum pernah menerapkan kebijakan fleksibilitas tempat kerja (flexiplace). Kebijakan bekerja dari rumah untuk pertama kalinya diterapkan oleh PT Bank Syariah X karena adanya tuntutan dari pemerintah terkait kondisi pandemi. Penggunaan media teknologi untuk berkomunikasi seperti video conference, selama ini mayoritas hanya digunakan untuk rapat dengan pihak-pihak eksternal perusahaan, namun kini telah menjadi gaya baru dalam keseharian bekerja untuk rapat dengan tim internal perusahaan yang sedang bekerja dari rumah. CEO PT Bank Syariah X menambahkan, era kenormalan baru (new normal) bagi dunia perbankan adalah layanan berbasis teknologi. Salah satu hikmah pandemi yaitu menyadarkan bank syariah bahwa teknologi digital bukan hanya monopoli perusahaan teknologi finansial atau bank-bank bermodal besar (Ucu, 2020).

Kemajuan informasi dan teknologi di era digital saat ini, semakin memungkinkan karyawan untuk bekerja secara fleksibel kapanpun dan dimanapun (Yasuhiro \& Vione, 2020). Fleksibilitas kerja dalam hal waktu (flexitime) dan tempat (flexiplace), seperti saat bekerja dari rumah dengan didukung oleh perangkat teknologi yang menunjang untuk bekerja, saat ini dikenal dengan istilah new ways of working atau gaya kerja baru (Demerouti, dkk., 2014).

Survei terhadap 1.140 karyawan dari berbagai sektor industri di seluruh Indonesia menunjukkan bahwa karyawan cenderung merasa bahagia selama menjalani kebijakan bekerja dari rumah di masa pandemi (Hami \& Ashriyana, 2020). Penelitian kualitatif kepada 23 karyawan perusahaan teknologi di Slovakia menunjukkan bahwa adopsi gaya kerja baru berpengaruh pada bertambahnya waktu yang dapat dihabiskan bersama keluarga dan meningkatkan atmosfer kekeluargaan, meskipun di sisi lain dapat membuat urusan pekerjaan dan rumah tangga menjadi samar (Fedakova \& Istonova, 2017). Temuan lain pada studi quasi-eksperimen yang dilakukan oleh Nijp, dkk. (2016) terhadap 2.912 karyawan di institusi keuangan Belanda, menunjukkan hasil bahwa terdapat perbedaan antara kelompok yang menjalani gaya kerja baru dan kelompok kontrol, yaitu pada kelompok gaya kerja baru, karyawan berhasil mengalami penurunan angka stres dan kelelahan pada tingkat medium effect. Penelitian tersebut menunjukkan bahwa adopsi gaya kerja baru ditemukan mampu menurunkan tingkat stres pada karyawan.

Berdasarkan pemaparan latar belakang masalah di atas, peneliti hendak melihat pengaruh keseimbangan kehidupan-kerja sebagai faktor internal individu dan gaya kerja baru sebagai faktor eksternal organisasi terhadap stres kerja pada karyawan PT Bank Syariah X. Individu yang memiliki keseimbangan kehidupan-kerja yang tinggi diduga akan menurunkan tingkat stres kerja karyawan, begitu pula dengan individu yang menerapkan kebijakan gaya kerja baru, diduga juga akan berpengaruh terhadap menurunnya tingkat stres kerja. Dari penelitian ini, harapannya bisa diketahui faktor mana yang berpengaruh lebih kuat terhadap stres kerja karyawan PT Bank Syariah X. Topik penelitian ini sangat relevan di era kenormalan baru yang sedang kita hadapi 
Tsalitsa Haura Syarifah \& Arum Etikariena. Keseimbangan Pekerjaan Dan Kehidupan Pribadi Serta Gaya Kerja Baru, Bagaimana Dampaknya Terhadap Stres

bersama dengan adanya kebijakan bekerja dari rumah dan menuntut optimalisasi peningkatan penggunaan teknologi dalam bekerja.

Penentuan variabel prediktor dalam penelitian ini juga dikuatkan dengan data hasil analisis bibliometrik pada 1.000 artikel Microsoft Academics yang dijaring menggunakan Publish or Perish 7 dan dianalisis menggunakan VOSviewer pada tahun 2020. Data menunjukkan bahwa area penelitian stres kerja yang berkaitan dengan keseimbangan kehidupan-kerja dan desain kerja, dalam hal ini gaya kerja baru masih berada pada zona hijau. Hasil tersebut menginformasikan bahwa penelitian pada topik-topik tersebut sudah mulai dilakukan namun jumlahnya masih terbatas sehingga masih sangat dibutuhkan untuk dapat memperkuat teori pada variabel stres kerja.

Berdasarkan latar belakang tersebut, maka dirumuskan beberapa permasalahan dalam penelitian ini, antara lain (1) apakah keseimbangan kehidupan-kerja berpengaruh secara signifikan terhadap stres kerja? (2) Apakah gaya kerja baru berpengaruh secara signifikan terhadap stres kerja? (3) Apakah keseimbangan kehidupan-kerja dan gaya kerja baru secara bersama-sama berpengaruh signifikan terhadap stres kerja? Penelitian ini diharapkan mampu menjawab permasalahan penelitian dan memperkaya khazanah ilmu pengetahuan psikologi di bidang industri dan organisasi, terkait topik stres kerja serta faktor-faktor yang mempengaruhinya, dalam hal ini keseimbangan kehidupan-kerja dan gaya kerja baru.

Adapun hipotesis yang hendak diuji pada penelitian ini, yaitu (1) keseimbangan kehidupan-kerja berpengaruh secara signifikan terhadap stres kerja. (2) Gaya kerja baru berpengaruh secara signifikan terhadap stres kerja. (3) Keseimbangan kehidupan-kerja dan gaya kerja baru secara bersama-sama berpengaruh signifikan terhadap stres kerja. Diharapkan penelitian studi kasus ini dapat bermanfaat bagi seluruh organisasi yang sedang menghadapi perubahan drastis di masa pandemi pada beberapa waktu terakhir.

\section{METODE PENELITIAN}

Penelitian ini menggunakan pendekatan kuantitatif yaitu studi korelasional. Desain penelitian ini berupa cross-sectional study yang meneliti variabel keseimbangan kehidupan-kerja dan gaya kerja baru sebagai variabel bebas, serta stres kerja sebagai variabel terikat. Populasi dalam penelitian ini adalah karyawan tetap kantor pusat PT Bank Syariah X sejumlah 846 orang per tahun 2020.

Target partisipan minimal berdasarkan penghitungan $\mathrm{G}^{*}$ Power yaitu sejumlah 147 orang. Teknik pengambilan sampel dilakukan menggunakan non-probability sampling dengan teknik convenience sampling. Teknik convenience sampling dipilih karena pihak perusahaan menyebarkan kuesioner online kepada seluruh karyawan tetap kantor pusat PT Bank Syariah X, kemudian jumlah partisipan didapatkan berdasarkan kesediaan. Metode penelitian ini telah lolos kaji etika penelitian dengan nomor 877/FPsi.Komite Etik/PDP04.00/2020 dari Fakultas Psikologi Universitas Indonesia.

Alat ukur stres kerja pada penelitian ini dikembangkan oleh Shukla dan Srivastava (2016). Total item alat ukur ini berjumlah 9 dengan 4 item yang mewakili dimensi time stress dan 5 item yang mewakili anxiety stress. Terdapat dua dimensi utama pada alat ukur ini, yaitu time stress dan anxiety stress. Time stress merupakan perasaan berada di bawah tekanan yang konstan atau terus menerus. Sedangkan, anxiety stress merupakan perasaan-perasaan cemas yang berkaitan dengan pekerjaan. Skala ini memiliki 6 pilihan jawaban, yaitu (1) Sangat Tidak Setuju, (2) Tidak Setuju, (3) Agak Tidak Setuju, (4) Agak 


\section{Psycho Idea, Volume 19 Nomer 01 Tahun 2021}

Setuju, (5) Setuju, dan (6) Sangat Setuju. Contoh itemnya adalah "Seringkali, pekerjaan saya menjadi beban yang berat".

Alat ukur keseimbangan kehidupan-kerja menggunakan adaptasi dari Bell, Rajendran, dan Theiler (2012) dari alat ukur Work-Family Balance milik Hill, dkk. (2011). Alat ukur ini berjumlah 5 item dengan 1 unfavourable item. Total skor didapatkan dengan menjumlah seluruh skor dari tiap item setelah membalik (reverse) item yang bersifat unfavourable. Terdapat 6 pilihan jawaban pada skala ini, seperti skala pada stres kerja. Contoh item pada alat ukur keseimbangan kehidupan-kerja adalah "Mudah bagi saya untuk menyeimbangkan tuntutan pekerjaan dengan kehidupan pribadi saya".

Alat ukur gaya kerja baru menggunakan skala new ways of working milik Van Steenbergen, dkk. (2018). Skala ini berisi 5 buah item setelah diadaptasi berdasarkan hasil uji keterbacaan. Pada penelitian ini, terdapat item yang digugurkan karena berdasarkan masukan dari expert judgement tidak relevan dengan konteks organisasi di Indonesia, yakni item terkait flexidesk. Terdapat 6 pilihan jawaban yang sama dengan dua skala sebelumnya. Contoh item alat ukur gaya kerja baru adalah "Saya menggunakan teknologi informasi (seperti smartphone dan laptop), sehingga saya dapat bekerja kapanpun dan dimanapun".

Metode analisis data yang digunakan antara lain penghitungan statistik deskriptif untuk melihat gambaran demografi responden. Metode selanjutnya menggunakan analisis regresi berganda (multiple regression) untuk melihat pengaruh variabel prediktor terhadap variabel outcome pada aplikasi SPSS untuk menguji hipotesis penelitian. Teknik statistik regresi yang digunakan adalah menggunakan metode enter yang dipilih karena semua variabel prediktor diperkirakan memiliki pengaruh terhadap variabel outcome, namun tidak diketahui variabel prediktor mana yang memiliki pengaruh paling tinggi atau tidak diketahui variabel bebas mana yang akan menghasilkan persamaan prediksi yang paling baik. Oleh karena itu, semua variabel prediktor dimasukkan dalam pengolahan SPSS secara bersamaan tanpa melihat urutan variabel prediktor mana yang memiliki pengaruh paling tinggi hingga rendah terhadap variabel outcome (Field, 2009).

\section{HASIL DAN PEMBAHASAN}

Responden penelitian yang didapatkan menggunakan teknik convenience sampling pada penelitian studi kasus ini berjumlah 154 orang karyawan tetap kantor pusat PT Bank Syariah X di kantor pusat. Response rate penelitian ini sebesar 18,2\%. Berikut adalah data demografis responden.

Tabel 1.

[Data Demografis Responden]

\begin{tabular}{lccc}
\hline Karakteristik & Kategori & Frekuensi & Persentase \\
\hline Jenis kelamin & Laki-Laki & 93 & $60,4 \%$ \\
\cline { 2 - 4 } & Perempuan & 61 & $39,6 \%$ \\
\hline \multirow{3}{*}{ Usia } & $<30$ tahun & 34 & $22,1 \%$ \\
\cline { 2 - 4 } & $30-40$ tahun & 83 & $53,9 \%$ \\
\cline { 2 - 4 } & $40-50$ tahun & 32 & $20,8 \%$ \\
\cline { 2 - 4 } $\begin{array}{l}\text { Rata-rata durasi } \\
\text { kerja/minggu }\end{array}$ & $>50$ tahun & 5 & $3,2 \%$ \\
\hline & $<40$ jam & 8 & $5,2 \%$ \\
\hline
\end{tabular}


Tsalitsa Haura Syarifah \& Arum Etikariena. Keseimbangan Pekerjaan Dan Kehidupan Pribadi Serta Gaya Kerja Baru, Bagaimana Dampaknya Terhadap Stres

Kerja?

Pada Tabel 1, dapat dilihat bahwa dari 154 orang karyawan tetap kantor pusat PT Bank Syariah X, mayoritas responden yang berpartisipasi pada penelitian ini merupakan karyawan laki-laki sejumlah 93 orang $(60,4 \%)$ dan sisanya perempuan. Sebagian besar responden $(53,9 \%)$ yaitu sebanyak 83 orang responden berada pada rentang usia 30-40 tahun. 34 orang $(22,1 \%)$ responden berusia di bawah 30 tahun, $20,8 \%$ berusia $40-50$ tahun, sedangkan sisanya berusia di atas 50 tahun. Berikutnya, rata-rata durasi bekerja karyawan mayoritas melebihi jam kantor pada umumnya, yaitu sebanyak 94 orang (61\%) bekerja lebih lama dari 40 jam seminggu. Kemudian, disusul dengan 33,8\% karyawan yang rata-rata bekerja selama 40 jam seminggu, dan sisanya hanya 5,2\% orang karyawan yang mengaku bekerja kurang dari 40 jam seminggu.

Hasil uji reliabilitas pada masing-masing skala dapat dilihat pada Tabel 2. Hasil menunjukkan bahwa koefisien Alpha Cronbach alat ukur stres kerja adalah sebesar 0,85. Kemudian, koefisien reliabilitas alat ukur keseimbangan kehidupan-kerja sebesar 0,82. Sedangkan, angka koefisien reliabilitas alat ukur gaya kerja baru adalah sebesar 0,78. Ketiga alat ukur ini dapat dikatakan memiliki konsistensi internal yang baik (Kaplan \& Sacuzzo, 2013). Adapun hubungan antar variabel keseimbangan kehidupan-kerja, gaya kerja baru, stres kerja, dan variabel demografi selanjutnya diuji menggunakan teknik korelasi pearson sebagai berikut.

Tabel 2.

[Uji Reliabilitas dan Hubungan Antar Variabel Penelitian, serta Variabel Demografi]

\begin{tabular}{lcccccc}
\hline Karakteristik & $\mathbf{1}$ & $\mathbf{2}$ & $\mathbf{3}$ & $\mathbf{4}$ & $\mathbf{5}$ & $\mathbf{6}$ \\
\hline Jenis Kelamin & - & & & & & \\
\hline Usia & -.14 & - & & & & \\
\hline Rata-Rata Lama Bekerja/Minggu & $-.16^{*}$ & .10 & - & & & \\
\hline Keseimbangan Kehidupan-Kerja & .10 & -.03 & -.09 & $(\alpha .82)$ & & \\
\hline Gaya Kerja Baru & .14 & .14 & .01 & $.18^{*}$ & $(\alpha .78)$ \\
Stres Kerja & -.08 & -.06 & .05 & $-.56^{* *}$ & -.06 & $(\alpha .85)$ \\
**Signifikan pada LOS 0,01 (two-tailed), *Signifikan pada LOS $0,05($ two-tailed)
\end{tabular}

Tabel 2 juga menunjukkan bahwa terdapat hubungan yang negatif dan signifikan antara keseimbangan kehidupan-kerja dan stres kerja $(r=-0,56, p<0,01)$. Hal ini menandakan bahwa semakin tinggi tingkat keseimbangan kehidupan-kerja, maka semakin rendah tingkat stres kerja karyawan. Berikutnya, gaya kerja baru tidak berkorelasi dengan stres kerja $(r=-0,06, p>0,05)$. Hasil uji korelasi juga menunjukkan adanya hubungan antar variabel keseimbangan kehidupan-kerja dan gaya kerja baru $(r=0,18, p<0,05)$. Hal ini berarti karyawan yang memiliki keseimbangan kehidupan-kerja yang tinggi ditemukan juga menerapkan gaya kerja baru yang tinggi. Temuan selanjutnya menunjukkan adanya korelasi yang signifikan antara variabel jenis kelamin dengan ratarata lama bekerja dalam seminggu $(r=0,16, p<0,05)$, yaitu laki-laki ditemukan cenderung bekerja dengan durasi lebih lama dibanding karyawan perempuan. Di sisi lain, seluruh variabel demografi yang diukur pada penelitian ini tidak ada yang berhubungan dengan skor stres kerja karyawan.

Pada tabel 3 di bawah ini, didapatkan hasil persamaan regresi sebagai berikut: Stres kerja $=49,18+(-1,04)$. Koefisien regresi keseimbangan kehidupan-kerja adalah sebesar -1,04 artinya setiap kenaikan skor sebesar 1 pada keseimbangan kehidupan-kerja, akan 


\section{Psycho Idea, Volume 19 Nomer 01 Tahun 2021}

menurunkan skor sebesar 1,04 pada stres kerja. Sedangkan, koefisien regresi gaya kerja baru tidak dimasukkan ke dalam persamaan regresi karena menunjukkan hasil yang tidak signifikan.

Tabel 3.

[Koefisien Regresi Masing-Masing Variabel Prediktor]

\begin{tabular}{lccccc}
\hline Variabel & $\boldsymbol{B}$ & $\boldsymbol{S E}$ & $\boldsymbol{\beta}$ & $\boldsymbol{t}$ & Sig. \\
\hline Constant & 49,18 & 3,10 & & 15,84 & .000 \\
\hline Keseimbangan Kehidupan-Kerja & -1.04 & .13 & -.56 & $-8,19$ & .000 \\
\hline Gaya Kerja Baru & .06 & .12 & .04 & .53 & .594 \\
\hline
\end{tabular}

Hasil regresi pada tabel 3 juga menemukan bahwa keseimbangan kehidupan-kerja memiliki pengaruh yang negatif dan signifikan terhadap stres kerja karyawan $(\beta=-0,56$, $p<0,01)$. Sedangkan, gaya kerja baru ditemukan tidak berpengaruh secara signifikan terhadap stres kerja $(\beta=0,04, p>0,05)$. Oleh sebab itu, dapat dikatakan bahwa keseimbangan kehidupan-kerja merupakan variabel prediktor yang berpengaruh lebih kuat terhadap stres kerja dibandingkan dengan variabel gaya kerja baru.

Tabel 4.

[Hasil Analisis Uji Model Regresi Berganda]

\begin{tabular}{|c|c|c|c|c|c|c|c|}
\hline Aspek $^{\mathrm{a}}$ & $R$ & $R^{2}$ & $S S$ & $d f$ & $M S$ & $F$ & Sig. \\
\hline Regresi & .557 & .31 & 3745,43 & 2 & 1872,72 & 33,98 & $.000^{\mathrm{b}}$ \\
\hline Residual & & & 8320,91 & 151 & 55,10 & & \\
\hline Total & & & 12066,34 & 153 & & & \\
\hline
\end{tabular}

Uji statistik untuk menguji hipotesis yang terakhir adalah dengan melihat hasil uji model regresi berganda untuk melihat pengaruh keseimbangan kehidupan-kerja dan gaya kerja baru secara bersama-sama terhadap stres kerja. Hasil analisis uji model pada Tabel 4 menunjukkan bahwa keseimbangan kehidupan-kerja dan gaya kerja baru secara bersama-sama berpengaruh secara signifikan terhadap stres kerja, $F(2,151)=33,98$, $p<0,01$. Nilai $R^{2}$ sebesar 0,31 menunjukkan bahwa $31 \%$ proporsi varians stres kerja dapat dijelaskan oleh keseimbangan kehidupan-kerja, sedangkan 69\% sisanya dipengaruhi oleh faktor lain yang tidak diukur dalam penelitian ini.

Hasil penelitian ini menemukan bahwa keseimbangan kehidupan-kerja sebagai faktor personal individu dan gaya kerja baru sebagai faktor lingkungan organisasi secara bersama-sama memiliki pengaruh terhadap stres kerja karyawan. Hal ini sejalan dengan pendekatan teori Person-Environment Fit terhadap stres yang dikembangkan oleh Edwards dan Cooper (2013), yang menjelaskan penyebab terjadinya stres yaitu dikarenakan rendahnya korespondensi antara karakteristik personal yang berasal dari internal diri individu dalam hal ini adalah kemampuan menyeimbangkan aspek kehidupan dan pekerjaan dengan faktor lingkungan dalam hal ini desain kerja fleksibel yang disebut dengan variabel gaya kerja baru.

Riset ini menemukan bahwa keseimbangan kehidupan-kerja berpengaruh secara negatif dan signifikan terhadap stres kerja pada karyawan kantor pusat PT Bank Syariah $\mathrm{X}$. Hasil ini mendukung temuan pada riset-riset sebelumnya yang menyebutkan bahwa keseimbangan kehidupan-kerja memiliki hubungan yang negatif dan signifikan dengan 
Tsalitsa Haura Syarifah \& Arum Etikariena. Keseimbangan Pekerjaan Dan Kehidupan Pribadi Serta Gaya Kerja Baru, Bagaimana Dampaknya Terhadap Stres

variabel stres kerja (Jaharuddin \& Zainol, 2019; Kumara \& Fasana, 2018; Brough, dkk., 2014; Smith \& Gardner, 2007). Temuan ini menjelaskan bahwa semakin tinggi keseimbangan kehidupan-kerja seorang karyawan akan berpengaruh terhadap menurunnya tingkat stres kerja. Sebaliknya, apabila keseimbangan kehidupan-kerja individu rendah maka dapat meningkatkan tingkat stres kerja yang dirasakan.

Salah satu strategi pengelolaan stres kerja bagi karyawan adalah dengan menerapkan gaya kerja baru yang menurut Demerouti, dkk. (2014) terdiri dari unsur fleksibilitas waktu kerja, fleksibilitas tempat kerja, dan penggunaan media teknologi komunikasi terkini dalam bekerja. Dari sisi organisasi, kebijakan yang disarankan adalah melakukan adaptasi desain kerja karyawan seperti penerapan flextime dan work-home transition (Yogeshwaran, 2016).

Menurut Rennecker dan Godwin (2005) penggunaan smartphone sebagai teknologi komunikasi terkini juga merupakan gaya kerja baru yang banyak diadopsi di berbagai tempat kerja saat ini. Parasuraman dan Greenhaus (2002) menyebutkan bahwa penggunaan smartphone dapat meningkatkan tingkat responsiveness, memberikan informasi secara real time, mempercepat proses pengambilan keputusan, dan meningkatkan fleksibilitas dalam bekerja, sehingga memberikan dampak yang positif dalam kehidupan dan pekerjaan karyawan.

Beberapa studi yang dilakukan oleh para peneliti sebelumnya, menunjukkan hubungan antara gaya kerja baru dan stres kerja dalam arah yang berbeda-beda. Hubungan antara gaya kerja baru dan stres kerja tidak selalu ditemukan negatif, dalam arti semakin tinggi adopsi gaya kerja baru akan menurunkan tingkat stres kerja. Namun, sebagian tokoh lain justru menemukan sebaliknya.

Derks dan Bekker (2010) menyebutkan bahwa salah satu elemen gaya kerja baru, yakni penggunaan teknologi komunikasi elektronik memiliki dampak terhadap peningkatan stres kerja. Dampak negatif dari kemajuan teknologi tersebut yaitu karyawan mendapatkan terlalu banyak informasi (information overload) yang memberikan banyak tuntutan pekerjaan yang berbeda-beda dan dapat dibaca sekaligus pada waktu yang sama, sehingga memunculkan tekanan untuk memberikan respon secara cepat setelah mengetahui informasi tersebut (work overload). Penelitian lain oleh Rennecker dan Derks (2012) juga menyebutkan bahwa salah satu sumber stressor karyawan dari penggunaan pesan elektronik adalah banyaknya jumlah dan panjangnya pesan yang diterima.

Konektivitas penuh selama 24 jam 7 hari menggunakan internet ternyata memiliki dampak terhadap bertambahnya jam kerja menjadi lebih panjang sehingga mengakibatkan menurunnya tingkat keseimbangan kehidupan-kerja (Ya-Yuan, dkk., 2019) dikarenakan adanya gangguan dari keluarga atau teman-teman saat bekerja (Allen, dkk., 2003), serta batasan antara kehidupan pekerjaan dan kehidupan pribadi menjadi samar (Derks \& Bakker, 2011; Jarvenpaa \& Lang, 2005).

Berdasarkan penjabaran hasil riset yang meneliti hubungan antara penggunaan teknologi pada gaya kerja baru dan stres kerja, dapat dilihat bahwa pengaruh penerapan gaya kerja baru pada diri karyawan sangat bervariasi dalam mempengaruhi tingkat stres individu. Oleh sebab itu pada penelitian ini, hasil analisis menunjukkan tidak terdapat pengaruh antara gaya kerja baru terhadap stres kerja. Peneliti mencurigai adanya variabel lain yang dapat menjelaskan kuat lemahnya hubungan tersebut sebagai moderator hubungan gaya kerja baru dan stres kerja. 


\section{Psycho Idea, Volume 19 Nomer 01 Tahun 2021}

Beberapa variabel yang berpotensi menjadi moderator pada hubungan antara variabel gaya kerja baru dan stres kerja antara lain usia, jenis kelamin, atau tipe kepribadian sebagaimana disebutkan oleh Cummings dan Worley (2015) sebagai faktorfaktor yang mempengaruhi bagaimana individu berespons terhadap stressor. Variabel lainnya yang juga dapat dipertimbangkan sebagai mediator adalah status keorangtuaan.

Para karyawan yang berstatus sebagai orang tua, menurut Rexrode dan Weber (2020) dapat berpotensi mengalami tingkat stres dan kelelahan yang lebih karena harus memikirkan skenario pengasuhan untuk anak selama mereka bekerja dari rumah. Selama masa Pembatasan Sosial Berskala Besar (PSBB) yang mendorong karyawan untuk bekerja dari rumah, di saat yang bersamaan pemerintah juga meliburkan pembelajaran tatap muka di sekolah dan lembaga pendidikan dari usia dini hingga pendidikan tinggi. Menurut Rexrode dan Weber (2020), tanpa bantuan pengasuhan anak, orang tua akan mengalami stres dan kelelahan.

Penyebab lainnya yang mengakibatkan hipotesis alternatif ketiga pada penelitian ini ditolak dapat pula diakibatkan oleh penerapan kebijakan bekerja dari rumah sesuai arahan dari pemerintah merupakan suatu kewajiban yang harus diikuti dan bukan merupakan pilihan yang menjadi kewenangan karyawan untuk menentukan tempat untuk bekerja. Saat ini, sistem kerja karyawan masih rutin masuk ke kantor dengan pembagian shift hari kerja sehingga jumlah karyawan yang masuk dapat berkurang hingga $50 \%$ (Hendrianto, 2020).

Kantor pusat PT Bank Syariah X menerapkan kebijakan bekerja dari rumah bukan merupakan inisiasi oleh PT Bank Syariah X yang hendak membuat kebijakan flexiplace, melainkan kewajiban untuk mengikuti regulasi dari pemerintah guna menekan angka penyebaran virus covid-19. Maka dari itu, karyawan belum benar-benar memiliki kewenangan untuk menentukan sendiri darimana ia hendak bekerja seperti konsep gaya kerja baru pada penelitian ini.

Salah satu kendala yang didapati pada pelaksanaan penelitian ini dan mungkin berpengaruh terhadap hasil penelitian salah satunya adalah pada proses pengambilan data. Variabel gaya kerja baru berdasarkan definisinya tidak hanya meliputi penggunaan alat telekomunikasi sebagai perangkat kerja, melainkan juga penerapan fleksibilitas waktu dan tempat kerja. Karakteristik kerja pada karyawan di industri perbankan baik konvensional maupun syariah, seperti yang telah dibahas di atas cenderung belum terlalu menerapkan gaya kerja baru tersebut ditinjau dari kebijakan fleksibilitas waktu dan tempat.

Sementara, adanya penerapan sistem bekerja dari rumah pada sebagian karyawan sangat bergantung pada unit kerja dan perannya di perusahaan apakah di bagian pelayanan langsung atau tidak, sehingga tidak semua karyawan tetap merasakan pelaksanaan kebijakan yang sama terkait fleksibilitas waktu dan tempat bekerja. Sedangkan, proses penyebaran kuesioner yang dapat dilakukan oleh perusahaan adalah melalui email blast kepada seluruh pegawai tetap, tanpa dapat menyaring apakah karyawan tersebut dapat bekerja dari rumah dan menggunakan flexi time atau tidak.

Limitasi pada penelitian ini diantaranya adalah masih terbatasnya jumlah partisipan yaitu sebanyak 101 orang. Diharapkan, apabila memungkinkan menambah jumlah sampel yang lebih besar, mungkin saja didapatkan hasil penelitian yang berbeda. Selain itu, limitasi lainnya adalah bentuk penelitian payung yang menggabungkan seluruh skala pengukuran peneliti pada satu kuesioner untuk disebar bersamaan. Salah satu keuntungannya adalah dapat lebih efisien dan hemat waktu, namun konsekuensi yang bisa didapatkan adalah efek kelelahan yang dialami oleh responden terutama dalam 
Tsalitsa Haura Syarifah \& Arum Etikariena. Keseimbangan Pekerjaan Dan Kehidupan Pribadi Serta Gaya Kerja Baru, Bagaimana Dampaknya Terhadap Stres

menjawab pertanyaan yang jumlahnya banyak. Sementara, dua skala pengukuran yang digunakan pada penelitian ini berada pada urutan paling akhir, sehingga dikhawatirkan, tingkat fokus dan motivasi partisipan dalam mengisi kuesioner bisa menurun.

Hasil yang didapatkan pada penelitian ini tetap berkontribusi positif dalam pengembangan ilmu pengetahuan, khususnya pada konstruk stres kerja dan kaitannya dengan variabel prediktor yaitu keseimbangan kehidupan-kerja dan gaya kerja baru yang berdasarkan hasil uji bibliometrics masih membutuhkan banyak penelitian untuk memperkaya temuan di bidang tersebut. Namun demikian, penelitian selanjutnya dapat diperluas pada jenis-jenis industri yang lainnya di luar perbankan dan tidak hanya di bidang pelayanan. Serta dapat menambah variabel-variabel prediktor lainnya untuk dapat menjelaskan secara lebih komprehensif dinamika antar variabel yang mempengaruhi stres kerja karyawan, khususnya di masa pandemi seperti saat ini.

\section{KESIMPULAN}

Berdasarkan hasil analisis terhadap 154 orang partisipan pada penelitian ini, dapat disimpulkan beberapa temuan sebagai berikut. Pertama, keseimbangan kehidupan-kerja berpengaruh secara signifikan terhadap stres kerja pada karyawan kantor pusat PT Bank Syariah X. Oleh sebab itu, hipotesis pertama penelitian ini dapat diterima. Temuan berikutnya yaitu gaya kerja baru tidak berpengaruh signifikan terhadap stres kerja karyawan kantor pusat PT Bank Syariah X. Maka dari itu, hipotesis kedua penelitian ini ditolak. Selanjutnya, keseimbangan kehidupan-kerja dan gaya kerja baru secara bersamasama memiliki pengaruh yang signifikan terhadap stres kerja karyawan kantor pusat PT Bank Syariah X. Oleh sebab itu, hipotesis ketiga penelitian ini diterima. Hasil temuan penelitian ini menunjukkan bahwa keseimbangan kehidupan-kerja sebagai faktor internal individu merupakan faktor yang lebih kuat dalam mempengaruhi stres kerja dibandingkan dengan gaya kerja baru sebagai faktor eksternal organisasi.

Saran yang dapat dipertimbangkan oleh peneliti selanjutnya antara lain melakukan penelitian dengan variabel dan model yang sama pada perusahaan di industri yang berbeda-beda. Dapat pula dilakukan perbandingan dengan industri yang bukan bergerak di bidang pelayanan atau bersinggungan langsung dengan pelanggan, terutama yang memang memiliki kebijakan gaya kerja baru. Peneliti berikutnya juga dapat menambah partisipan penelitian untuk memprediksi hasil semakin akurat. Selanjutnya, menambah data pada variabel demografi yang terkait, seperti status keorangtuaan dan jenis pekerjaan untuk memperkaya temuan penelitian. Berikutnya, peneliti juga dapat melakukan kontrol terhadap common method bias untuk meningkatkan kontrol pada penelitian.

\section{DAFTAR PUSTAKA}

Abidin, Z. (2020). Program Ceria Menjadi Andalan untuk Meningkatkan Kinerja Karyawan Pada Masa Transisi. Diakses dari https://muamalat-institute.com/?p=685.

Bell, A., Rajendran, D., \& Theiler, S. (2012). Job stress, wellbeing, work-life balance and work-life conflict among Australian academics. Electronic Journal of Applied Psychology. 8(1): 25-37. DOI: 10.7790/ejap.v8i1.320.

Cummings, T. G., \& Worley, C. G. (2015). Organization Development and Change. 10th ed. Ohio: Cengage Learning. 


\section{Psycho Idea, Volume 19 Nomer 01 Tahun 2021}

Derks, D., \& Bakker, A. B. (2010). The impact of e-mail communication on organizational life. Cyberpsychology. Journal of Psychosocial Research on Cyberspace, 4(1).

Derks, D., \& Bakker, A. B. (2011). The Impact of Smartphone Use of Work-Home Interference, Recovery and Daily Well-being: A Diary Study. Manuscript under review.

Demerouti, E., Derks, D., Brummelhuis, L. L. T., \& Bakker, A. B. (2014). New ways of working: Impact on working conditions, work-family balance, and well-being. The Impact of ICT on Quality of Working Life. Berlin: Springer Science and Business Media LLC.

Edwards J.R. \& Cooper C.L. (2013) The Person-Environment Fit Approach to Stress: Recurring Problems and Some Suggested Solutions. In: Cooper C.L. (eds) From Stress to Wellbeing Volume 1. London: Palgrave Macmillan. https://doi.org/10.1057/9781137310651_5.

Fedakova, D. \& Istonova, L. (2017). Slovak IT-employees and new ways of working: Impact on work-family borders and work-family balance. Cekoslovenska Psychologie, 68-83.

Field, A. (2009). Discovering Statistics Using SPSS (Third Ed.). Singapore: SAGE Publication Asia-Pacific Pte Ltd.

Hendrianto, A. (2020). Wawancara L1 di kantor pusat PT Bank Syariah X.

Hill, E. J., Hawkins, A. J., Ferris, M., \& Weitzman, M. (2001). Finding an extra day a week: The positive influence of perceived job flexibility on work and family life balance. Family Relations, 50(1), 49-58. DOI: 10.1111/j.1741-3729.2001.00049.x.

Hongwei H. \& Harris, L. (2020). The impact of covid-19 pandemic on corporate social responsibility and marketing philosophy. Journal of Business Research, 116, 176-182. DOI: $10.1016 /$ j.jbusres.2020.05.030.

Jaharuddin, N. S. \& Zainol, L. N. (2019). The impact of work-life balance on job engagement and turnover intention. The South East Asian Journal of Management, 13(1), 106-118. DOI: $10.21002 /$ seam.v13i1.10912.

Jarvenpaa, S., \& Lang, K. (2005). Managing the paradoxes of mobile technology. Information Systems Management Journal, 22, 7-23. DOI: 10.1201/1078.10580530/45520.22.4.20050901/90026.2.

Kalpna \& Malhotra, M. (2019). Relationship of work-life balance with occupational stress among female personnel of the central industrial security force (CISF), India. International Research Journal of Engineering and Technology (IRJET), 6(7), 13801387. e-ISSN: 2395-0056.

Kaplan, R. M. \& Saccuzzo, D. P. (2013). Psychological Testing: Principles, Applications, and Issues (8th ed.). Belmont: Wadsworth.

Kumara, J., \& Fasana, S. F. (2018). Work life conflict and its impact on turnover intention of employees: The mediation role of job satisfaction. International Journal of Scientific and Research Publications, 8(4), 478-484. DOI: 10.29322/IJSRP.8.4.2018.p7666.

Nijp, H. H., Beckers, D. G., Van de Voorde, K. Geurts, S. A., \& Kompier, M. A. (2016). Effects of new ways of working on work hours and work location, health, and jobrelated outcomes. Chronobiology International, 33(6), 604-618. DOI: 10.3109/07420528.2016.1167731.

Parasuraman, S., \& Greenhaus, J.H. (2002). Toward reducing some critical gaps in workfamily research. Human Resource Management Review, 12, 299-312. DOI: 10.1016/S1053-4822(02)00062-1.

Puspaningtyas, L. (2020). Di Tengah Pandemi, Bank Muamalat Luncurkan Program Ceria. Diakses dari https://republika.co.id/berita/qc2fsl423/di-tengah-pandemi-bankmuamalat-luncurkan-program-ceria. 
Tsalitsa Haura Syarifah \& Arum Etikariena. Keseimbangan Pekerjaan Dan

Kehidupan Pribadi Serta Gaya Kerja Baru, Bagaimana Dampaknya Terhadap Stres

Kerja?

Rennecker, J., \& Godwin, L. (2005). Delays and interruptions: A self-perpetuating paradox of communication technology use. Information and Organization, 15, 247-266. DOI: 10.1016/j.infoandorg.2005.02.004.

Rennecker, J., \& Derks, D. (2012). Email overload: fine tuning the research lens. In D. Derks \& A. B. Bakker (Eds.), The Psychology of Digital Media at Work. London, UK: Psychology Press.

Rexrode, C. \& Weber, L. (2020). Working parents are hitting their coronavirus breaking point and paying for it. The Wall Street Journal. Diakses dari https://www.wsj.com/articles/working-parents-are-hitting-their-coronavirus-breakingpointand-paying-for-it-11597483801.

Shaffer, M. A., Sebastian R., B., Dimitrova, M., Lazarova, M., Chen, S., Westman, M., \& Wurtz, O. (2016). Work and family role adjustment of different types of global professionals: Scale development and validation. Journal of International Business Studies, 47(2), 113-139. DOI:10.1057/JIBS.2015.26.

Shukla, A. \& Srivastava, R. (2016). Development of a short questionnaire to measure an extended set of role expectation conflict, coworker support and work-life balance: The new job stress scale. Cogent Business \& Management, 3: 1134034. DOI: 10.1080/23311975.2015.1134034.

Smith, J., \& Gardner, D. (2007). Factors affecting employee use of work life balance initiatives. New Zealand Journal of Psychology, 36(1), 3-11. DOI: 10.2307/30034926.

Sullivan, C (2012). Remote working and work-life balance. In N. P. Reilly, M. J. Sirgy, \& C.

A. Gorman (Eds.), International Handbooks of Quality-of-Life. Work and Quality of Life: Ethical Practices in Organizations (p. 275-290). Springer Science Business Media. https://doi.org/10.1007/978-94-007-4059-4 15.

Taylor, S. (2019). The Psychology of Pandemics: Preparing for The Next Global Outbreak of Infectious Disease. Newcastle: Cambridge Scholar Publishing.

Ucu, K. R. (2020). Asa Bank Syariah di Tengah Pandemi Corona. Diakses dari https://republika.co.id/berita/qcijtq282/asa-bank-syariah-di-tengah-pandemi-corona/.

Van Steenbergen, E. F., van der Ven, C., Peeters, M. C. W., \& Taris, T. W. (2018). Transitioning towards new ways of working: Do job demands, job resources, burnout, and engagement change?. Psychological Reports, 121(4), 736-766. DOI: $10.1177 / 0033294117740134$.

Yahsyi, A. (2018). Ikhtiar Bank Muamalat Lolos Dari Krisis Ke Krisis. Diakses dari https://www.cnnindonesia.com/ekonomi/20180302132644-81-279947/ikhtiar-bankmuamalat-lolos-dari-krisis-ke-krisis.

Ya-Yuan, H., Chyi-Huey, B., Chien-Ming, Y., Ya-Chuan, H., Tzu-Ting, L., \& Chih-Hung, L. (2019). "Long hours' effects on work-life balance and satisfaction". BioMed Research International. https://doi.org/10.1155/2019/5046934.

Yogeshwaran, P. (2016). Job stress and its impact on work life balance of the employees working in BPO's. Shanlax International Journal of Management, 4(1), 103-106. 